\title{
The experimental investigation of the failure of load-bearing masonry walls supported by a deflecting structure
}

\author{
Adam Piekarczyk \\ Department of Building Structures; Faculty of Civil Engineering; Silesian University of Technology; \\ Akademicka St. 2, 44-100 Gliwice, Poland; \\ Adam.Piekarczyk@polsl.pl (D)0000-0002-5790-9560
}

\begin{abstract}
The paper presents selected results of tests of full-scale masonry walls linearly supported on a deflecting beam. The walls with thin bed joints and unfilled head joints were $4.55 \mathrm{~m}$ long and $2.45 \mathrm{~m}$ high, and were made of group 1 calcium silicate masonry units. The tests included walls with and without openings.

The tests were carried out in a specially designated and constructed test stand, which allowed simultaneous vertical load on the upper edge of the wall and vertical deflection of the beam supporting this wall. During the test, measurements of mutual displacements of six points on the wall surface were carried out. On both faces of masonry specimens, the changes of the length of the measuring bases connecting these six points were recorded.

Walls without openings were detached from the central part of the supporting beam at a deflection not exceeding $2 \mathrm{~mm}$. Walls with one door opening also cracked at an early stage of tests. In this case, a detachment from the supporting beam and cracking at the ends of the lintel occurred because of the rotation of the pillars connected by the lintel above the opening. In walls with two door openings, first cracks were formed at the ends of lintels due to the rotation of pillars with a small deflection of the supporting beam, less than $3 \mathrm{~mm}$. Whereas, in walls with door and window openings, first cracks occurred under the window and at the end of the lintel in the outer pillar of the wall.
\end{abstract}

Keywords: AAC blocks masonry, floors deflections, damages of masonry walls, transversal deformations of masonry

\section{Introduction}

Damage to masonry walls may result from uneven displacements of structural elements adjacent to these walls and on which they are supported. The above-mentioned elements include foundations, lintel beams and ceiling elements, for which a few millimetres of deflection can lead to cracking of masonry walls. 
Damage to walls supported on ceilings results from the uneven movement of structural ceiling members. These displacements are most often deflections of reinforced concrete structure. Deflection, which is vital for a masonry wall supported on RC ceiling, is the effect of loads that occur after the erection of masonry and after removal or partial removal of ceiling props. The deflection of the ceiling results from permanent loads that affect the ceiling structure after masonry is erected, i.e. the self-weight of the floors, installations and suspended finishing systems, as well as other finishing materials such as plastering. The other reason of this deflection is imposing of service load which acts directly on the ceiling, and in the case of load-bearing walls, permanent and imposed loads transmitted via these walls from higher floors. It is also worth mentioning that the deflection of the loaded ceiling increases with time due to creep and shrinkage of concrete, and may rise several times over the decades compared to the deflection after the construction of a wall. Due to the low early strength of a wall and rheological processes taking place in the masonry, when determining the deflection of a ceiling after erection of a wall, it is not needed to take into account its self-weight without plaster layers, but only in case if walls are constructed on a completely unpropped ceiling.

Prevention of wall damage usually consists in reducing ceiling deflection at the design and construction stages. When designing, attention should be paid to the appropriate static assumption, including the use of ceilings supported on all edges on supports with the highest possible stiffness, shortening spans of multi-span systems, construction of supports with similar stiffness on all floors. At the construction stage, it is essential to make sure that the walls on the ceiling are erected only after the props have been removed, preferably completely. Masonry walls should be made with the use of deformable cement-lime mortars with normal thickness joints. It is desirable to finish the walls supported on the ceiling in such a way that plasterings of the walls and ceiling are separated from each other. Due attention is also needed to properly connect the vertical edges of the walls with the others, which minimises cracks at the junction. The use of reinforcement placed in masonry bed joints can also reduce the width of cracks, but usually does not prevent their occurrence, especially in the case of the walls with openings. More information on how to limit ceiling deflection, calculations of deflections, and their permissible values can be found in works [1]-[3] and standards [4]-[8].

Part of the results of tests of full-scale walls made of calcium-silicate masonry units was published in articles [9] and [10], and walls made of autoclaved aerated concrete blocks - in paper [11]. Besides, in the paper [12] it was proposed that the ratio of deflection of span length of the linear element supporting the masonry wall should be limited to $1 / 2000$ and that the tensile strength of the masonry should be not less than $0.2 \mathrm{~N} / \mathrm{mm}^{2}$. In the paper [13], the authors suggest limiting of the ratio of deflection to span length to $1 / 3330$. Studies of masonry walls at a scale 1:2 made of concrete blocks were published in [14]. Limiting the deflection of the structure supporting the masonry walls to $1 / 500$ and 1/1000 of their span length, in the case of walls without openings and with openings, respectively, was suggested in the study [15]. Tests of masonry walls with and without openings supported on reinforced concrete beams are presented in the paper [16]. The tests of walls in the scale with openings made of solid ceramic masonry units was carried out by the authors of the study [17] and [18]. The first cracks occurred at a deflection not exceeding $2 \mathrm{~mm}$, which was about 1/1000 of the span length of the supporting beam. The authors of publications [22]-[26] were also involved in experimental tests and theoretical analyses related to the problem of masonry walls supported on deflecting structure. 


\section{The specimens and test stand}

\subsection{The materials and specimens}

Specimens were made of group 1 according to PN-EN 1996-1-1 [27] calcium-silicate blocks, $250 \mathrm{~mm}$ long, $180 \mathrm{~mm}$ wide and $220 \mathrm{~mm}$ high; mean compressive strength was determined in accordance with PN-EN 772-1 [28] $f_{\mathrm{B}}=17.7 \mathrm{~N} / \mathrm{mm}^{2}$ and normalised compressive strength $f_{\mathrm{b}}=21.8 \mathrm{~N} / \mathrm{mm}^{2}$. Designated masonry mortar with mean compressive strength $f_{\mathrm{m}}=12.5 \mathrm{~N} / \mathrm{mm}^{2}$ determined according to PN-EN 998-2 [29] standard was used.

Full-scale walls with total nominal length of $4.55 \mathrm{~m}$ and nominal height of $2.45 \mathrm{~m}$ with thin bed joints and unfilled head joints were tested. The type A walls did not have openings (Fig 1a). The type B specimens contained one door opening asymmetrical to the vertical axis of the wall (Fig. 1b). The type $\mathrm{C}$ walls contained two door openings located symmetrically to the vertical axis of the wall (Fig. 1c). The type D walls had one door and one window opening (Fig. 1d). Above the door openings of the Type B and Type C specimens, single-span reinforced concrete lintels were placed with a section width of $180 \mathrm{~mm}$ and height of $220 \mathrm{~mm}$. Above the door and window openings in the Type $\mathrm{D}$ walls, there was the double-span continuous lintel with the same cross-sectional dimensions as single-span lintels. The length of the lintel was chosen in such a way that the length of the support on the masonry was not less than $125 \mathrm{~mm}$. Two walls of each type were tested - a total of eight specimens.

a)

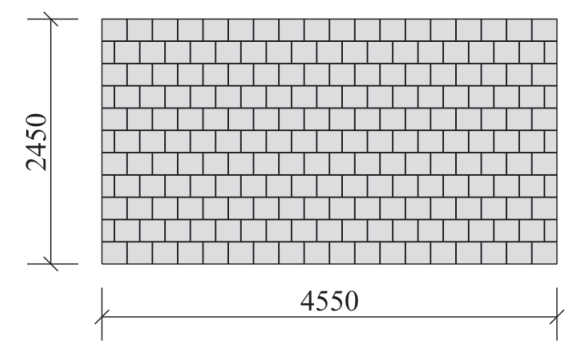

c)

Type C

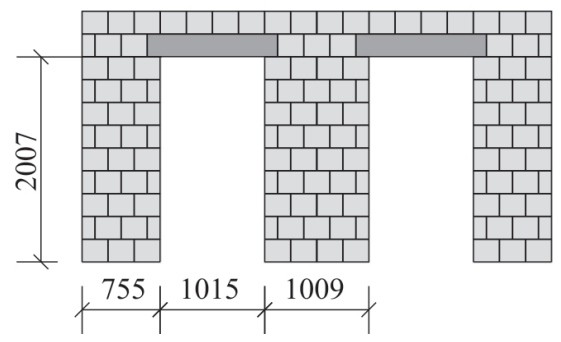

b)

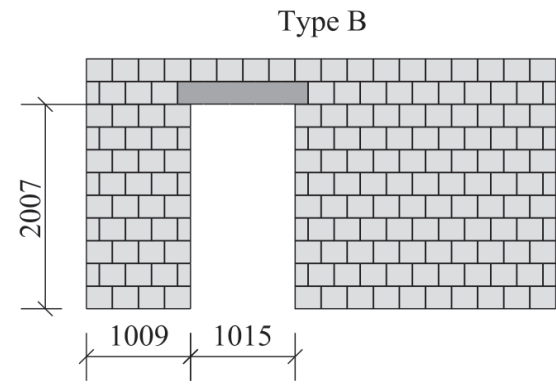

d)

Type D

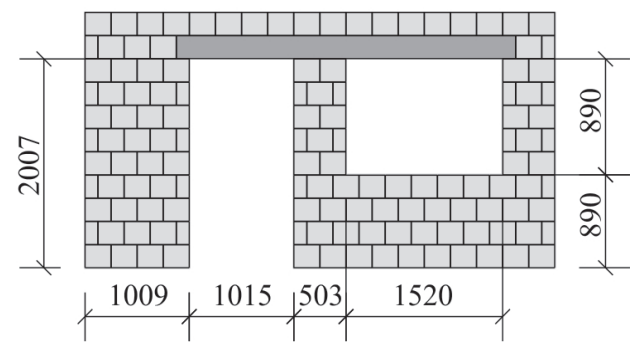

Fig. 1. The full-scale specimens: a) without openings, b) with one asymmetrically arranged door opening, c) with two door openings, d) with door and window openings. Source: the author's own study

\subsection{The test stand and testing technique}

The tests were carried out in the specially designated test stand shown in Fig. 2. The walls were built directly on a steel beam supported along the entire length during construction 
(Fig. 2; item 8). After they were erected, a reinforced concrete ring beam $180 \mathrm{~mm}$ wide and $200 \mathrm{~mm}$ high was placed on the mortar layer (Fig. 2; item 5). Hydraulic cylinders induced the vertical load in the form of $F$ forces with a range up to $500 \mathrm{kN}$ (Fig. 2; item 3). Measurement of the force $F$ was also made with a load cell with a range up to $500 \mathrm{kN}$ (Fig. 2; item 2). The load was transferred to the specimens via steel transverse beams (Fig. 2; item 4).

The vertical displacements of the beam supporting the masonry wall reflected the deflection of the real reinforced concrete ceiling members, lintel beams or foundations. The flexural rigidity of the steel beam of the stand (Fig. 2; item 8) was intentionally low, thus it was possible to force additional vertical displacements, except for those resulting from the vertical load of $F$ forces. The additional deflection of the structure supporting the masonry wall results from the loads acting directly on the ceiling (self-weight and service loads) and also are the effect of delayed concrete deformations related to creep and shrinkage. Therefore, the vertical beam displacements $\delta_{\mathrm{vi}}$ in the tests were carried out in two ways. Firstly, the deflection was caused by the vertical load $F$ transmitted through the wall, and then increased to the expected value with a system of elements designed for this purpose and equipped with hydraulic cylinders with a range up to $150 \mathrm{kN}$ and load cells with up to 50 and $100 \mathrm{kN}$ (Fig. 2; item 10 to 13). The deflection of the steel beam supporting the wall was measured using displacement transducers with a measuring range of $\pm 50 \mathrm{~mm}$ attached to steel angles that were connected to the supports of the test stand regardless of the deflecting beam (Fig. 2; item 7). Vertical displacements of the supporting beam were measured on both sides of the wall in $1 / 6$ and $5 / 6$ span $\left(\delta_{\mathrm{v} 1}\right)$, in $1 / 3$ and $2 / 3$ span $\left(\delta_{\mathrm{v} 2}\right)$ and half-span $\left(\delta_{\mathrm{v} 3}\right)$. The expected deflection value was fixed with M30 screws (Fig. 2; item 14).

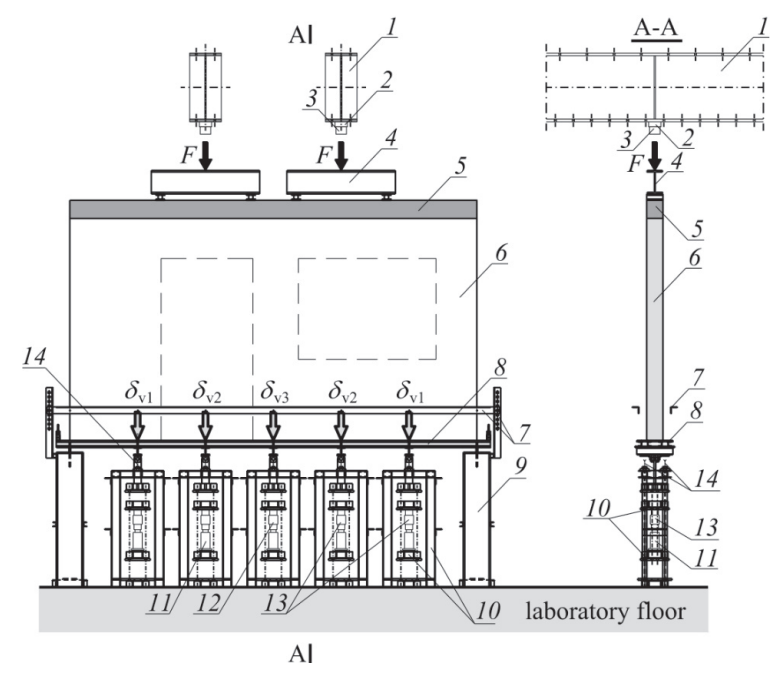

Fig. 2. The test stand: 1 - steel frame, 2 - load cell, 3-hydraulic jack, 4 - steel crossbeam, 5 - RC ring beam, 6 - tested wall, 7 - members of the system for measuring the vertical displacements, 8 - flexible wall support (steel beam), 9 - beam supports, 10 - elements of the system enforcing vertical displacements, 11 - hydraulic jack with a range up to $150 \mathrm{kN}, 12$ - load cell with a range up to $100 \mathrm{kN}, 13$ - load cell with a range up to $50 \mathrm{kN}, 14$ - screws for fixing the defections. Source: the author's own study

The deformations of the wall along eleven sections of the measuring bases located between six points on the wall surface were also measured. Deformations were recorded on both faces of the specimens. The measuring bases formed two rectangles, each $1.95 \mathrm{~m}$ long 
and $1.90 \mathrm{~m}$ high, which were conventionally described as the left-field "L" and right-field "R" - Fig. 3. Changes in the length of the measuring bases as a result of the action of vertical forces $F$ and deflections $\delta_{\mathrm{vi}}$ were measured using displacement transducers with a measuring range of \pm 5 and $\pm 10 \mathrm{~mm}$. Eighth deformation angles $\theta_{\mathrm{i}}$ were calculated on the basis of the changes in the length of sections indicated as $a_{\mathrm{i}}$ to $k_{\mathrm{i}}$ in Fig. 4 . For example, angle $\theta_{6}$ was determined from the following formula:

$$
\theta_{6}=\arcsin \left(\frac{c_{i}^{2}-h_{i}^{2}-g_{i}^{2}}{2 c_{i} h_{i}}\right)
$$

a)

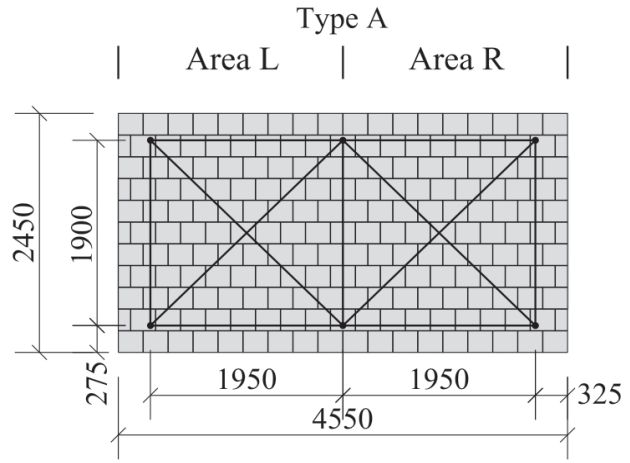

b)

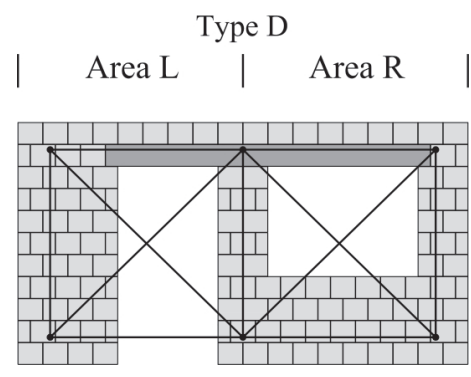

Fig. 3. The areas where measurements of wall deformations were made in the left-field „L” and right-field „R" based on changes in the length of sections of the measuring bases on the example of a wall: a) without openings, b) with door and window opening. Source: the author's own study

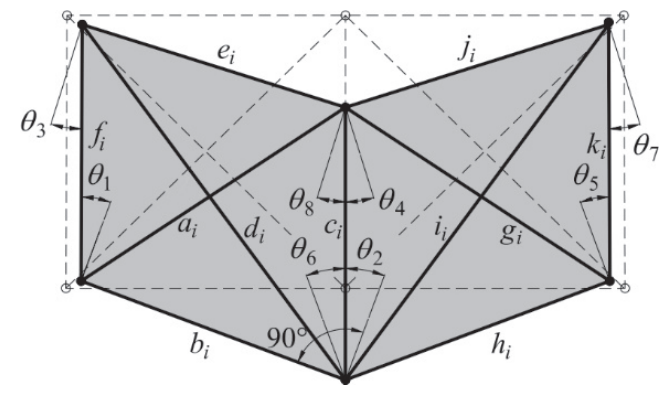

Fig. 4. The diagram of the method for determining the angles of deformation $\theta_{\mathrm{i}}$ on the basis of changes in the length of eleven sections of measuring bases $a_{\mathrm{i}} \ldots k_{\mathrm{i}}$. Source: the author's own study

\section{The mechanism of wall cracking and discussion of selected tests results}

Table 1 summarises selected values of parameters determined at the moment of the first visible occurrence of cracking. Table 2 contains the test results referring to the values obtained at failure of the specimens, for which it was not possible to obtain higher values of $F$ load. Tab. 1 and 2 in column 3 contain the values of the load on the upper edge of the wall $p_{\mathrm{i}}$, at which the walls cracked $p_{\mathrm{cr}}$ and failed $p_{\mathrm{u}}$ given in $\mathrm{kN} / \mathrm{m}^{2}$, i.e. equal to the average stress value in the horizontal cross-section of the wall as a result of the impact of $F$ forces. The load $p_{\mathrm{i}}$ was determined from the following equation:

$$
p_{i}=\frac{2 F_{i}}{L_{1} t^{\prime}}
$$


where $F_{\mathrm{i}}$ is the force transmitted to the wall from a single jack, $L_{1}$ is the wall length $\left(L_{1}=4.55 \mathrm{~m}\right)$, $t$ is the wall thickness $(t=0.18 \mathrm{~m})$.

Column 4 summarises the deflection values in the mid-span of the supporting beam $\delta_{1 / 2 \text {.cr }}$ and $\delta_{1 / 2 \text {.u }}$ accompanying the relevant load $\mathrm{p}_{\mathrm{i}}$. Column 5 in both tables shows the values of the ratio of the corresponding deflection in the middle of the beam span to its length $\delta_{1 / 2 . i} / L$ $(L=4.5 \mathrm{~m})$. The values of the deformation angle calculated for the moment of first crack occurrence $\theta_{\mathrm{cr}}$ and failure $\theta_{\mathrm{u}}$ are listed in column 6 on the left " $\mathrm{L}$ " and right " $\mathrm{R}$ " of the individual walls. Columns 7 and 8 of the tables show a description of the cracking mechanism and drawings which illustrate these damages.

Table 1. Selected test results obtained at the moment of first occurrence of cracking. Source: the author's own study

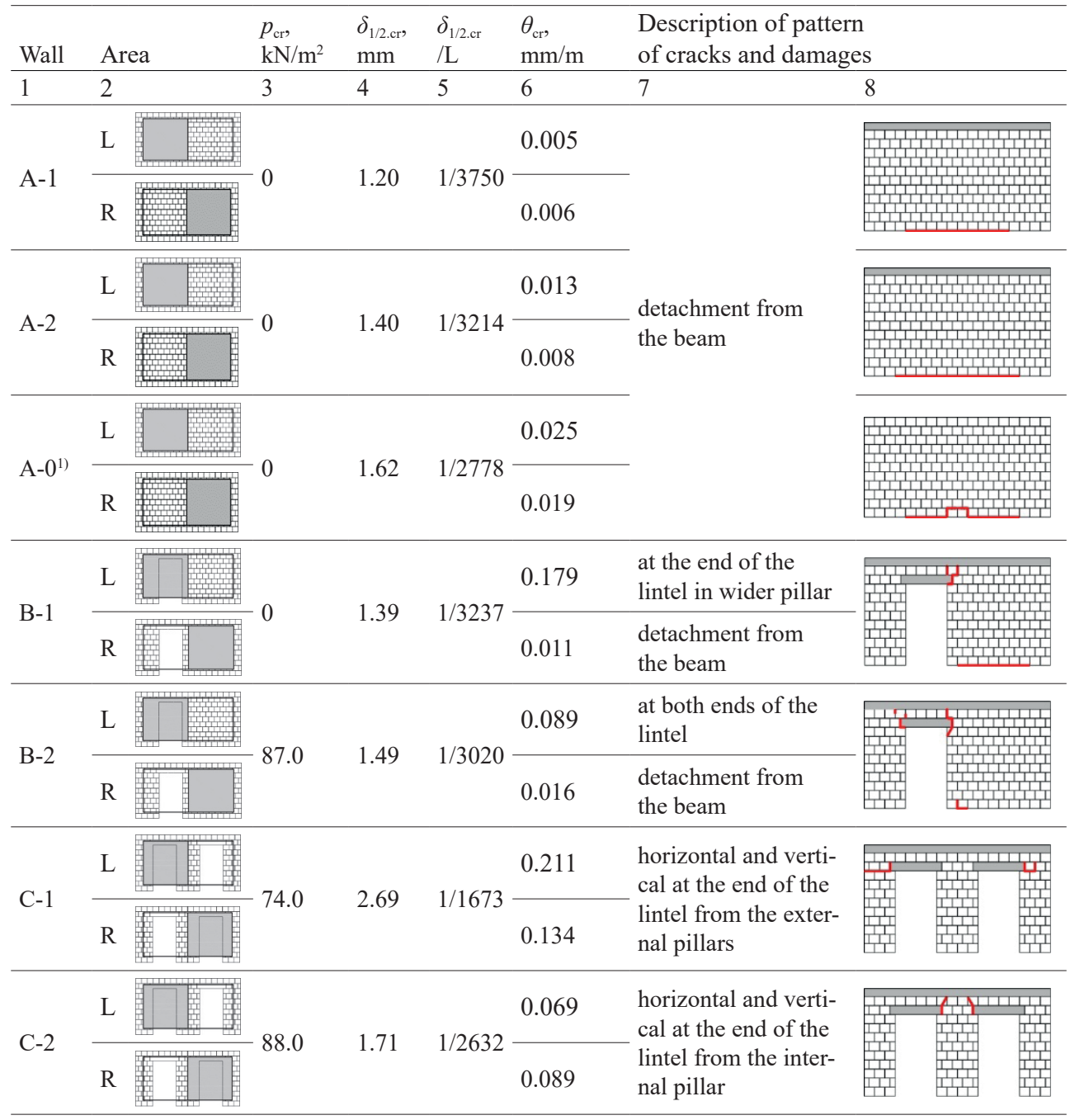

1) - wall without ring beam 
The experimental investigation of the failure of load-bearing masonry walls...

Table 1. (cont.) Continuation from the previous page. Source: the author's own study

\begin{tabular}{|c|c|c|c|c|c|c|c|}
\hline Wall & Area & $\begin{array}{l}p_{\mathrm{cr}} \\
\mathrm{kN} / \mathrm{m}^{2}\end{array}$ & $\begin{array}{l}\delta_{1 / 2 . \mathrm{cr}}, \\
\mathrm{mm}\end{array}$ & $\begin{array}{l}\delta_{1 / 2 . \mathrm{cr}} \\
/ \mathrm{L}\end{array}$ & $\begin{array}{l}\theta_{\mathrm{cr}} \\
\mathrm{mm} / \mathrm{m}\end{array}$ & $\begin{array}{l}\text { Description of patter } \\
\text { of cracks and damag }\end{array}$ & \\
\hline 1 & 2 & 3 & 4 & 5 & 6 & 7 & 8 \\
\hline \multirow[b]{2}{*}{ D-1 } & 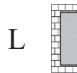 & \multirow[b]{2}{*}{78.0} & \multirow[b]{2}{*}{1.29} & \multirow[b]{2}{*}{$1 / 3488$} & 0.080 & no cracks & \multirow{2}{*}{ 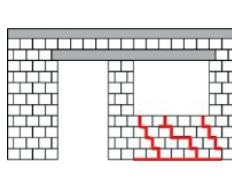 } \\
\hline & R & & & & 0.676 & $\begin{array}{l}\text { detachment from the } \\
\text { beam; oblique cracks } \\
\text { under the window }\end{array}$ & \\
\hline \multirow[b]{2}{*}{ D-2 } & L 铌 & \multirow[b]{2}{*}{0} & \multirow[b]{2}{*}{2.00} & \multirow[b]{2}{*}{$1 / 2250$} & 0.216 & no cracks & \\
\hline & R & & & & 3.52 & $\begin{array}{l}\text { detachment from } \\
\text { a beam; oblique } \\
\text { cracks under the } \\
\text { window; horizontal } \\
\text { and vertical cracks at } \\
\text { the end of the lintel } \\
\text { on an external pillar }\end{array}$ & 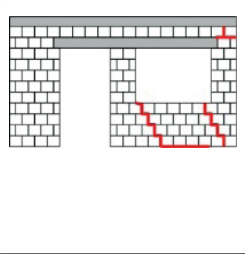 \\
\hline
\end{tabular}

For walls with door and window openings, a different cracking and failure mechanism was observed. A common feature was the detachment of the walls from the supporting beam, which in the case of walls without openings and containing both window and door opening always occurred at the beginning of the test with a slight deflection not exceeding $2.0 \mathrm{~mm}$ and without the load on the upper edge of the wall or with a small load.

In the case of walls without openings, two types of failure have been observed. One of the walls failed at relatively low load and deflection occured in a manner typical for bending elements, i.e. a vertical crack running through the entire height of the wall. Two walls without openings failed by diagonal cracks, but in the case of the wall without a reinforced concrete ring beam, a lower ultimate load and associated deflection were observed.

Table 2. Selected test results obtained at walls failure. Source: the author's own study

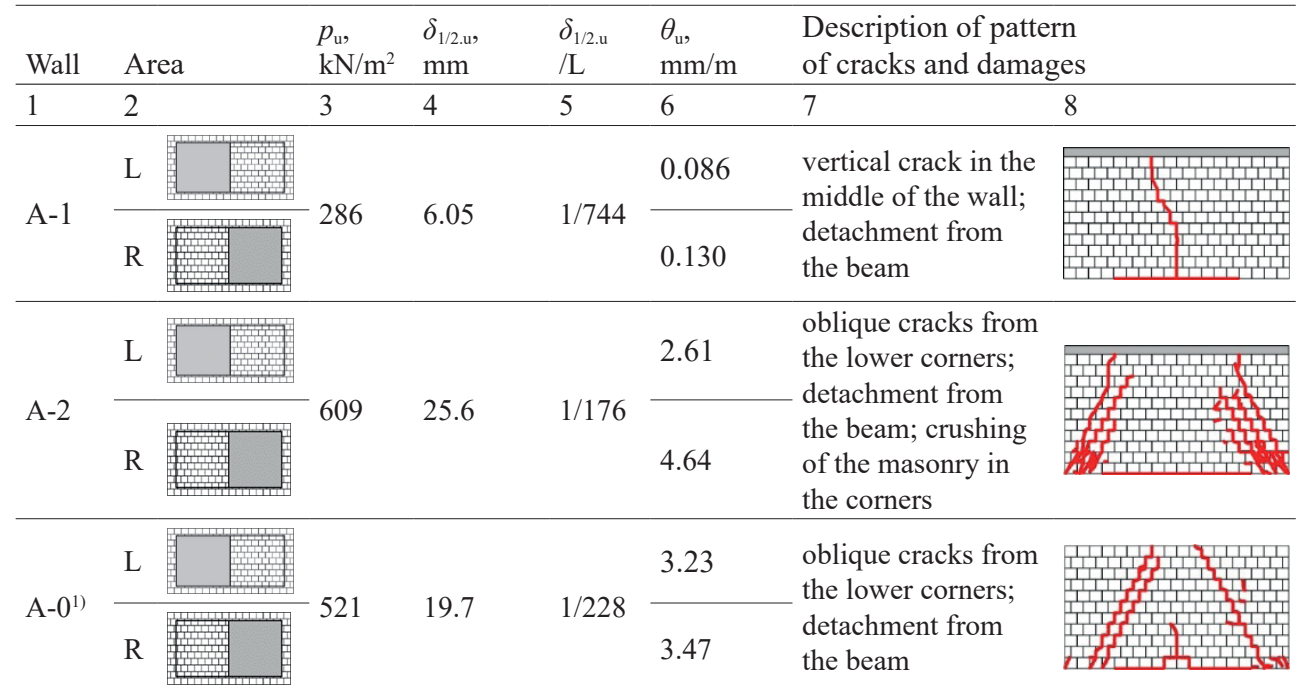

1) - wall without ring beam 
Table 2. (cont.). Continuation from the previous page. Source: the author's own study

\begin{tabular}{|c|c|c|c|c|c|c|c|}
\hline Wall & Area & $\begin{array}{l}p_{\mathrm{u}} \\
\mathrm{kN} / \mathrm{m}^{2}\end{array}$ & $\begin{array}{l}\delta_{1 / 2 . u}, \\
\mathrm{~mm}\end{array}$ & $\begin{array}{l}\delta_{1 / 2 . u} \\
/ \mathrm{L}\end{array}$ & $\begin{array}{l}\theta_{\mathrm{u}}, \\
\mathrm{mm} / \mathrm{m}\end{array}$ & $\begin{array}{l}\text { Description of pattern } \\
\text { of cracks and damages }\end{array}$ & \\
\hline 1 & 2 & 3 & 4 & 5 & 6 & 7 & 8 \\
\hline \multirow{3}{*}{ B-1 } & \multirow[t]{2}{*}{$\mathrm{L}$} & \multirow{3}{*}{391} & \multirow{3}{*}{11.2} & \multirow{3}{*}{$1 / 402$} & \multirow[t]{2}{*}{12.2} & \multirow{2}{*}{$\begin{array}{l}\text { horizontal and vertical } \\
\text { at the ends of the lintel; } \\
\text { diagonal cracking of the } \\
\text { pillar; detachment of } \\
\text { a part of the pillar sepa- } \\
\text { rated by the crack; crush- } \\
\text { ing of the masonry under } \\
\text { the lintel; detachment } \\
\text { from the beam }\end{array}$} & \multirow{3}{*}{ 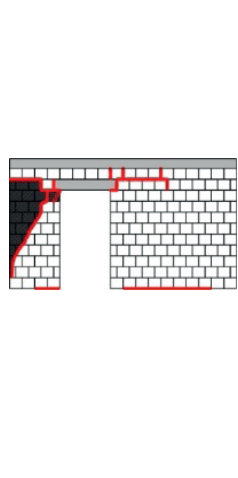 } \\
\hline & & & & & & & \\
\hline & $\mathrm{R}$ & & & & 1.15 & $\begin{array}{l}\text { horizontal and vertical at } \\
\text { the end of the lintel on } \\
\text { the wider pillar; detach- } \\
\text { ment from the beam }\end{array}$ & \\
\hline
\end{tabular}

at the ends of the lintel; detachment from the ring beam; detachment

$\mathrm{L}$

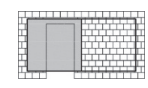

354

6.59

6.24

B-2

$\mathrm{R}$

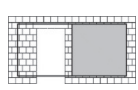

$\mathrm{L}$

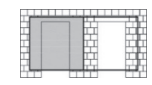

C-1

620

23.4

$1 / 192$

$\mathrm{R}$

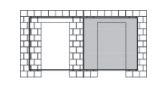
from the beam; under the lintel on the wider pillar; the opening of vertical joints over the lintel; diagonal cracking

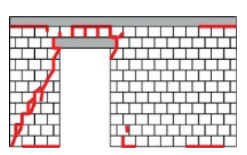
of the external pillar

horizontal at the end of 0.266 the ring beam; detachment from the beam horizontal and vertical at the ends of the lintel; under the lintel on the 13.3 side of the internal pillar; "stepped" cracking of the external pillar; detachment from the supporting beam horizontal and vertical at the ends of the lintel; 14.4 under the lintel on the side of the internal pillar; detachment from the beam

The first damages of Type B walls with one door opening appeared in the areas at the ends of the lintels and the wall was detached from the supporting beam. The failure of walls of this type consisted of diagonally cracking of the narrow pillar.

In the case of the Type $\mathrm{C}$ walls with two door openings, the first cracks occurred at the lintel ends at a deflection not exceeding $3 \mathrm{~mm}$ and a load not exceeding $90 \mathrm{kN} / \mathrm{m}^{2}$. The failure of this type of walls was manifested by the development of cracks at the ends of the lintels and the creation of a diagonal crack in one of the outer pillars. 
Table 2. (cont.) Continued. Source: own study

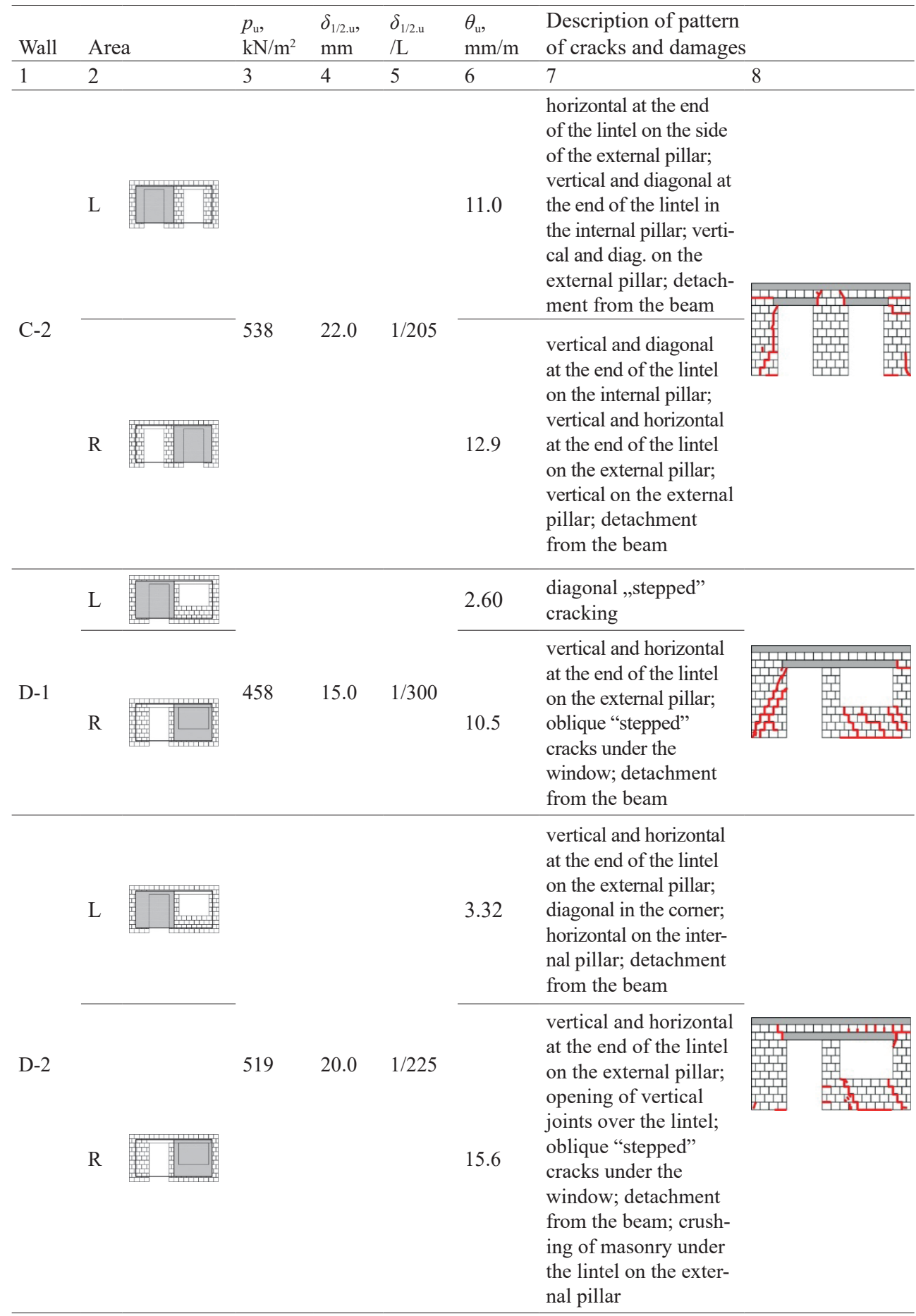


The first cracks in Type D walls after the wall was detached from the supporting beam were formed at a deflection not exceeding $2.0 \mathrm{~mm}$ under the window opening. They were "stepped" cracks. The failure of this type of wall consisted in crushing the masonry under the longer span of the lintel or diagonal cracking of the outer pillar adjacent to the door opening.

a)

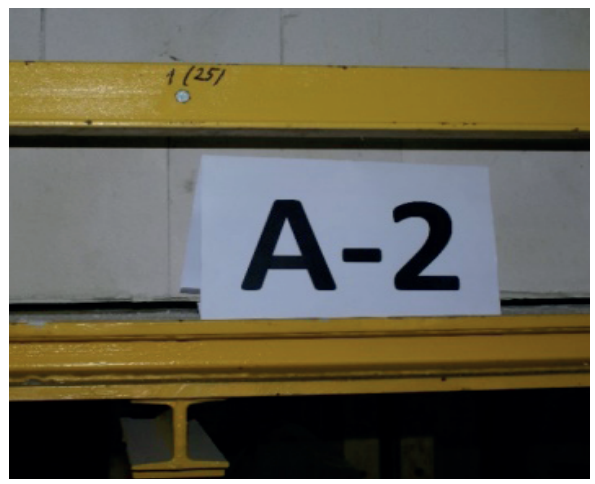

c)

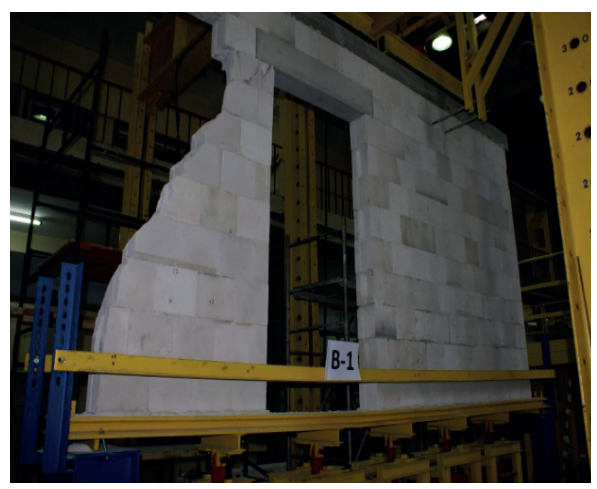

e)

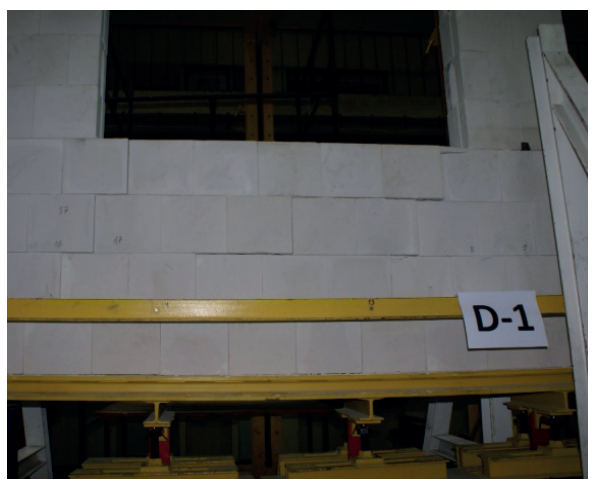

b)

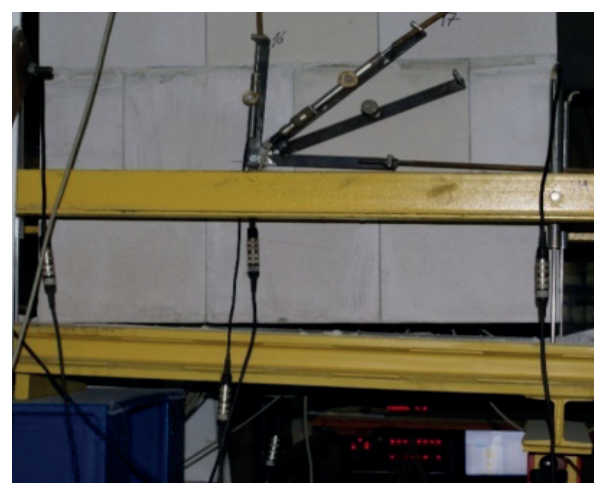

d)

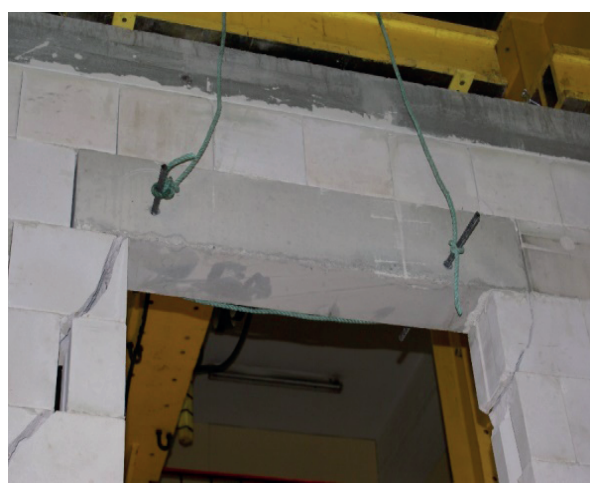

f)

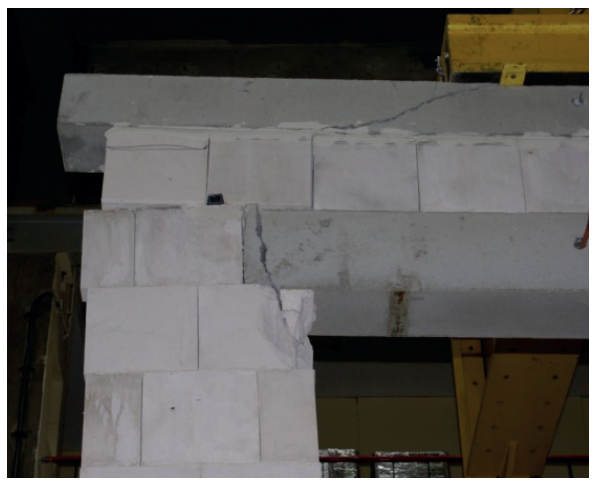

Fig. 5. Photographs of most common ways of cracking and failure of the walls: a) detachment of the lower edge of the A-2 wall, b) detachment of the lower part of the outer pillar of the C-1 wall, c) destruction of the pillar in the B-1 wall, d) destruction of the B-2 wall under the lintel, e) cracks in the wall D-1 under the window opening, f) failure of the outer pillar in the D-2 wall under the lintel. Source: the author's own study 


\section{Conclusions}

Based on the tests of full-scale masonry walls subjected to simultaneous compression and the effects of vertical displacements of the beam supporting these walls carried in the above-described range, it could be observed that:

- the first cracks occurred already with a small deflection of the supporting beam, not exceeding $2.7 \mathrm{~mm}$, which was less than 1/1700 beam span and zero or a low vertical load of the upper wall surface; this confirms the conclusions of [12] and [13] papers, which in order to minimise the possibility of damage of masonry walls proposed to limit vertical displacements of wall supporting elements to $1 / 2000$ or even $1 / 3330$ of their span;

- in the case of walls without openings, the detachment from the supporting beam in the central part occurred first;

- in walls with openings, the first cracks usually appeared at the ends of the lintels and also, in the case of walls with window and door openings, in the area of the wall under the window opening;

- one of the walls containing a single door opening and one wall without openings were damaged with deflection less than 1500 of the support beam span;

- in most cases, the deflection at failure did not exceed 1/300 of the span;

- in the case of geometrically asymmetrical walls, the effect of this asymmetry on the deformation angles of the left and right part of the wall was visible; in the Type B walls, the area without a door opening behaved almost like a rigid body compared to the other part of the wall weakened by the opening, which had an impact on the mechanism of failure of this type of wall;

- disproportions of deformation in the case of walls with both window and door opening were slightly smaller, although equally distinct; the part of the wall with a window opening suffered at least four times greater deformations, the measure of which was the angle of deformation.

\section{References}

[1] Drobiec Ł., Kubica J., „Zapobieganie zarysowaniom ścian murowanych opartych na stropach żelbetowych", Materiały Budowlane, no. 4, 2006.

[2] Nowicki M., „Zapobieganie uszkodzeniom murowanych ścian wypełniających spowodowanych uginaniem się żelbetowych stropów w budynkach mieszkalnych", Inżynier budownictwa, accessed on: 04.02.2014.

[3] Szulc J., „Ugięcia czynne stropów żelbetowych a uszkodzenia eleemntów opartych na stropach żelbetowych", Materiaty Budowlane, no. 4, 2013.

[4] PN-EN 1992-1-1 Eurocode 2: Design of concrete structures - Part 1-1: General rules and rules for buildings.

[5] PN-EN 15037-1 Precast Concrete Products - Beam-and-Block Floor Systems Part 1: Beams.

[6] ISO 4356 Bases for the design of structures. Deformations of buildings at the serviceability limit states.

[7] ACI 318-02 Building code requirements for structural concrete.

[8] DIN 1045-1 Concrete, reinforced and prestressed concrete structures. Part 1: Design and construction.

[9] Piekarczyk A., Jasiński R., "Distorsions and the way of damaging masonry walls supported on deflected structural elements", in $16^{\text {th }}$ International Brick and Block Masonry Conference - Trends, Innovations and Challenges. Taylor \& Francis Group, London 2016, pp. 1659-1666. 
[10] Piekarczyk A., "Cracking and Failure Mechanism of Masonry Walls Loaded Vertically and Supported by Deflecting Structural Member", in 3rd World Multidisciplinary Civil Engineering-ArchitectureUrban Planning Symposium, WMCAUS 2018, 18-22 June. Prague, Czech Republic. IOP Conference Series: Science and Engineering, vol. 471, 2019.

[11] Piekarczyk A., "Reinforced and Unreinforced AAC Masonry Walls Supported on Deflecting Structure", in $6^{\text {th }}$ International Conference on Autoclaved Aerated Concrete, September 4-6, 2018, University Potsdam. Ce/papers Ernst \& Sohn, A Wiley Brand, vol. 2, 2018, pp. 377-387.

[12] Meyerhof G., "Some recent foundation research and its application to design", The Structural Engineer, vol. 32, no. 4, 1953, pp. 55-93.

[13] Polshin D.E., Tokar R.A., "Maximum allowable non-uniform settlement of structure", in Proceedings of Fourth International Conference on Soil Mechanics and Foundation Engineering. Butterworths Scientific Publications, London, vol. 1, 1957, pp. 402-405.

[14] Rosenhaupt S., "Experimental Study on Masonry Walls on Beams", Journal of the Structural Division, (June 1962), pp. 137-166.

[15] Pfeffermann O., "Deformations admissible dans le batiment", CSTC Revue, 1981, Nlt 131, Bruxelles, p. 29.

[16] Wenzong X., Qinglin W., "A study of the behavior of the supporting beams on walls", in Third International Symposium on Wall Structures CIB. Warsaw, vol. 1, 1984, pp. 309-315.

[17] Holanda G., Ramalho M., Corrêa M., "Experimental and numerical analysis of masonry load-bearing walls subjected do differential settlements", in Proceedings of the $9^{\text {th }}$ North American Masonry Conference. Clemenson, USA, 2003, p. 134-145.

[18] Holanda G., Ramalho M., Corrêa M., "Experimental and numerical analysis of masonry walls with openings subjected do differential foundation settlements", in Proceedings of the $10^{\text {th }}$ North American Masonry Conference. St. Louis, USA, 2007, pp. 26-27.

[19] Henry A.W., Structural Brickwork. The MacMillan Press LTD, London, 1981.

[20] Capozucca R., "An approximate method for analysis of stress distribution in masonry walls", Masonry International, vol. 1, 1984, pp. 22-26.

[21] Henry A.W., Sinha B.P., Davies S.R., Design of Masonry Structures. E \& FN Spon, London, 1988.

[22] Valsangkar A.J., Dawe J.L., Seah C.K., "An Evaluation on Masonry Walls-foundation Interaction Using Finite Element Method", in Proceedings of the British Masonry Society, Proceedings of the Third International Masonry Conference, no. 6, (March 1994), pp. 144-146.

[23] Loots J.J., van Zijl G., "Experimental verification of settlement induced damage to masonry walls", in Proceedings of $13^{\text {th }}$ International Brick and Block Masonry Conference. Amsterdam, 2004.

[24] Martens D.R.W., Vermeltfoort A.T., "The Effect of the Position of Supports on the Behavior of Composite Masonry Walls", in Proceedings of $15^{\text {th }}$ International Brick and Block Masonry Conference. Florianopolis, Brasil, 2012.

[25] Moraes R.S., Serafim J.A., Parsekian G.A., "Macro modelling of the arch effect: A parametric study", in Proceedings of $15^{\text {th }}$ International Brick and Block Masonry Conference. Florianopolis, Brasil, 2012.

[26] Vermeltfoort A.T., "Practical Aspects of Testing Composite Action in Masonry Walls", in Proceedings of $15^{\text {th }}$ International Brick and Block Masonry Conference. Florianopolis, Brasil, 2012.

[27] PN-EN 1996-1-1 Eurocode 6: Design of masonry structures - Part 1-1: General rules for reinforced and unreinforced masonry structures

[28] PN-EN 772-1 Methods of tests for masonry units. Part 1: Determination of compressive strength.

[29] PN-EN 998-2 Specification for mortar for masonry Part 2: Masonry mortar. 